\title{
Efficacy of pharmacological therapies in patients with IBS with diarrhoea or mixed stool pattern: systematic review and network meta-analysis
}

\author{
Christopher J Black, ${ }^{1,2}$ Nicholas E Burr, ${ }^{1,2}$ Michael Camilleri (1), ${ }^{3}$ David L Earnest, ${ }^{4}$ \\ Eamonn MM Quigley, ${ }_{1}^{5}$ Paul Moayyedi, ${ }^{6}$ Lesley A Houghton, ${ }^{1}$ Alexander C Ford (1) 1,2
}

\begin{abstract}
- Additional material is published online only. To view please visit the journal online (http://dx.doi.org/10.1136/ gutjnl-2018-318160)

'Leeds Institute of Medical Research at St. James's, University of Leeds, Leeds, UK LLeeds Gastroenterology Institute, St. James's University Hospital, Leeds, UK

${ }^{3}$ Mayo Clinic, Rochester,

Minnesota, USA

${ }^{4}$ Division of Gastroenterology, The University of Arizona College of Medicine, Tucson, Arizona, USA

${ }^{5}$ Division of Gastroenterology and Hepatology, The Methodis Hospital, Weill Cornell Medical College, Houston, Texas, USA ${ }^{6}$ Department of Gastroenterology, McMaster University, Hamilton, Ontario, Canada
\end{abstract}

Correspondence to Professor Alexander C Ford, Leeds Gastroenterology Institute, St. James's University Hospital, Leeds LS9 7TF, UK; alexf12399@yahoo.com

CJB and NEB are joint first authors.

Received 26 December 2018 Revised 4 February 2019 Accepted 2 April 2019

Published Online First 17 April 2019

Check for updates

(c) Author(s) (or their employer(s)) 2020. No commercial re-use. See rights and permissions. Published by BMJ.

To cite: Black CJ, Burr NE, Camilleri $\mathrm{M}$, et al. Gut 2020;69:74-82.
ABSTRACT
Objective Over half of patients with IBS have either

diarrhoea (IBS-D) or a mixed stool pattern (IBS-M). The relative efficacy of licenced pharmacological therapies is unclear in the absence of head-to-head trials. We conducted a network meta-analysis to resolve this uncertainty.

Design We searched MEDLINE, Embase, Embase Classic, the Cochrane central register of controlled trials, and Clinicaltrials.gov through January 2019 to identify randomised controlled trials (RCTs) assessing the efficacy of licenced pharmacological therapies (alosetron, eluxadoline, ramosetron and rifaximin) in adults with IBS-D or IBS-M. Trials included in the analysis reported a dichotomous assessment of overall response to therapy, and data were pooled using a random effects model. Efficacy and safety of all pharmacological therapies were reported as a pooled relative risk with $95 \% \mathrm{Cls}$ to summarise the effect of each comparison tested. Treatments were ranked according to their $p$ score. Results We identified 18 eligible RCTs (seven alosetron five ramosetron, two rifaximin and four eluxadoline), containing 9844 patients. All were superior to placebo for the treatment of IBS-D or IBS-M at 12 weeks, according to the Food and Drug Administration (FDA)recommended endpoint for trials in IBS. Alosetron $1 \mathrm{mg}$ twice daily was ranked first for efficacy, based on the FDA-recommended composite endpoint of improvement in both abdominal pain and stool consistency, effect on global symptoms of IBS and effect on stool consistency. Ramosetron $2.5 \mu \mathrm{g}$ once daily was ranked first for effect on abdominal pain. Total numbers of adverse events were significantly greater with alosetron $1 \mathrm{mg}$ twice daily and ramosetron $2.5 \mu \mathrm{g}$ once daily, compared with placebo. Rifaximin $550 \mathrm{mg}$ three times daily ranked first for safety. Constipation was significantly more common with all drugs, except rifaximin $550 \mathrm{mg}$ three times daily. Conclusion In a network meta-analysis of RCTs of pharmacological therapies for IBS-D and IBS-M, we found all drugs to be superior to placebo, but alosetron and ramosetron appeared to be the most effective.

\section{INTRODUCTION}

IBS affects $10 \%$ of people worldwide and is one of the most common functional bowel disorders. ${ }^{1}$ The condition is characterised by abdominal pain, in association with defecation or a change in bowel habit. ${ }^{2}$ IBS accounts for a considerable proportion of
Significance of this study

What is already known on this subject?

- Patients with IBS with diarrhoea (IBS-D) or IBS with mixed stool pattern (IBS-M) have worse quality of life than those with IBS with constipation.

- Up to one-third of these patients use loperamide, but there is little evidence for its efficacy, and many patients report inadequate relief of symptoms.

- Although there are several licenced pharmacological therapies for IBS-D and IBS-M, which are often used as second-line therapy, their relative efficacy is unknown.

What are the new findings?

- We identified 18 randomised controlled trials of pharmacological therapies in IBS-D and IBS-M, containing 9844 patients, with all drugs significantly more effective than placebo.

- Alosetron $1 \mathrm{mg}$ twice daily was ranked the most effective in our primary analysis, using the Food and Drug Administration-recommended composite endpoint for trials in IBS.

- Ramosetron $2.5 \mu \mathrm{g}$ once daily was ranked the most effective for improvement in abdominal pain, and alosetron $1 \mathrm{mg}$ twice daily was best for improvement in stool consistency.

How might it impact on clinical practice in the foreseeable future?

- Antagonists of 5-hydroxytryptamine-3 (5$\mathrm{HT}_{3}$ ) receptors seem to perform best for the symptoms of IBS-D and IBS-M.

- These data suggest either access to existing, licenced 5- $\mathrm{HT}_{3}$ antagonists should be improved, or large trials of older $5-\mathrm{HT}_{3}$ antagonists, such as ondansetron, are required in patients with IBS-D and IBS-M.

referrals to gastroenterology across both secondary and tertiary care settings and, in the USA, is associated with annual direct costs of almost $\$ 1$ billion, as well as another $\$ 50$ million in indirect costs. ${ }^{3}$ There is a substantial impact on quality of life for patients with active symptoms, ${ }^{4}$ which is more pronounced for patients with IBS with diarrhoea (IBS-D) or IBS 
with mixed stool pattern (IBS-M) $)^{5}$ who account for over 50\% of people with IBS. ${ }^{1}$ These patients often report a fear of incontinence due to loose stools and urgency ${ }^{6}$ and can therefore find working and socialising extremely challenging. ${ }^{7}$ Although up to one-third of these patients use loperamide, ${ }^{8}$ a $\mu$-opioid agonist, as an antidiarrhoeal agent, there is little evidence for its efficacy in IBS, ${ }^{9}$ and many patients report inadequate relief of symptoms, other than diarrhoea, with the drug. ${ }^{8}$ In addition, although other well-established treatments for IBS, such as antispasmodics or tricyclic antidepressants, may improve abdominal pain, ${ }^{10} 11$ many are not licenced for treatment of IBS.

Consequently, over the last 20 years, a number of other pharmacological therapies have been licenced for the treatment of IBS-D and IBS-M. Although they have different mechanisms of action, in clinical practice, all these drugs tend to be used when first-line treatments have failed. Alosetron and ramosetron are both antagonists of the 5 -hydroxytryptamine- $3\left(5-\mathrm{HT}_{3}\right)$ receptor, an action that may serve to slow gastrointestinal transit, alter rectal compliance ${ }^{12} 13$ and reduce visceral sensitivity. ${ }^{14}$ Rifaximin is a minimally absorbed broad-spectrum antibiotic that has been tested in IBS-D and IBS-M, on the basis that alterations in gastrointestinal microbiota may, in part, be responsible for symptoms. ${ }^{15}$ Finally, eluxadoline is a peripherally acting mixed $\mu$-opioid and $\kappa$-opioid receptor agonist, and $\delta$-opioid receptor antagonist, with minimal oral bioavailability, which reduces visceral hypersensitivity and slows gastrointestinal transit. ${ }^{16}$

High-quality placebo-controlled randomised controlled trials (RCTs) have confirmed that all of these licenced drugs are effective treatments for IBS-D and/or IBS-M,,$^{917-21}$ but there have been no head-to-head trials conducted to evaluate relative efficacy. As it is unlikely that any such trials will be performed, we have conducted a network meta-analysis to allow comparisons to be made between all of these drugs, as well as to enable ranking of treatments, in order to inform clinical decisions. This is similar to our recent exercise for drugs used to treat IBS with constipation (IBS-C). ${ }^{22}$ The validity of such network metaanalyses can be undermined if there are differences in the design and endpoints used in individual RCTs. However, in this case, the efficacy of all these drugs has been assessed according to endpoints recommended currently for pharmacological therapies in IBS by the Food and Drug Administration (FDA). In addition, as many trials reported the efficacy of each of these drugs, in terms of their effect on individual symptoms, such as abdominal pain or stool consistency, relative efficacy for each drug according to each of these endpoints can also be assessed.

\section{METHODS}

\section{Search strategy and study selection}

MEDLINE (1947-January 2019), Embase, Embase Classic (1947-January 2019) and the Cochrane central register of controlled trials were searched to identify potential studies. In addition, we searched ClinicalTrials.gov for unpublished trials or supplementary data for potentially eligible studies. In order to identify studies published only in abstract form, conference proceedings (Digestive Diseases Week, American College of Gastroenterology, United European Gastroenterology Week and the Asian Pacific Digestive Week) between 2001 and 2019 were hand-searched. Finally, a recursive search was performed, using the bibliographies of all obtained articles.

Eligible RCTs examined the effect of licenced pharmacological therapies (alosetron, eluxadoline, ramosetron or rifaximin) in adult patients ( $>18$ years) with IBS-D or IBS-M (online supplementary table 1). The first period of cross-over RCTs were eligible for inclusion if they provided efficacy data prior to cross-over. The definitions of IBS of interest included either a clinician's opinion, or meeting specific diagnostic criteria, for example, the Rome criteria. Only RCTs that examined the efficacy of standard doses of the drugs of interest, and which compared them with each other, or with placebo, were considered eligible. A minimum follow-up duration of 12 weeks was required, in line with FDA recommendations for the design of treatment trials for functional gastrointestinal disorders. All endpoints were extracted at 12 weeks, even for RCTs providing efficacy data at other time points. This was done to ensure as much homogeneity as possible between individual trial results and to avoid overestimating the efficacy of one drug relative to another, as the placebo effect tends to wane with time. ${ }^{23}$ Studies had to report a dichotomous assessment of response to therapy. First and senior authors of studies were contacted to provide additional information on individual trials where required.

Two investigators (CJB and $\mathrm{ACF}$ ) conducted the literature search, independently from each other. Studies on IBS were identified with the terms: irritable bowel syndrome and functional disease(s), colon (both as medical subject headings and free-text terms) and IBS, spastic colon, irritable colon or functional adj5 bowel (as free-text terms). These were then combined using the set operator AND with studies identified with the following terms: alosetron, Lotronex, eluxadoline, Viberzi, Truberzi, ramosetron, Irribow, rifaximin and Xifaxan (all as free-text terms).

There were no language restrictions. Two investigators (CJB and ACF) evaluated all abstracts identified by the search for eligibility, again independently from each other. All potentially relevant papers were obtained and evaluated in more detail, using predesigned forms, in order to assess eligibility independently, according to the predefined criteria. Foreign language papers were translated where required. Where multiple articles for a single study were found, wherever possible, we extracted data from the fully published article but used supplementary data concerning any other endpoints of interest from secondary publications or ClinicalTrials.gov, where applicable and relevant. Disagreements between investigators were resolved by discussion.

\section{Outcome assessment}

We assessed the efficacy of all drugs, compared with each other or with placebo, in IBS-D and IBS-M in terms of failure to respond to therapy. The included eligible RCTs often used different primary endpoints. However, some of the trials adhered to FDA-recommended endpoints and reported treatment efficacy according to a composite of improvement in both abdominal pain and stool consistency, or we were able to obtain these data from the original investigators. Three of the RCTs of alosetron also applied these criteria retrospectively to a subset of patients in the phase III studies. In addition, because individual trials reported efficacy according to several other secondary endpoints, we were able to assess the efficacy of therapies according to other dichotomous endpoints to define response to treatment. These included: (A) relief of global IBS symptoms (global IBS symptom responder); (B) relief of abdominal pain (abdominal pain responder); and (C) improvement in stool consistency (stool consistency responder). Secondary outcomes included adverse events occurring as a result of therapy (overall numbers of adverse events, regardless of causality, as well as adverse events leading to study withdrawal, and individual adverse events, including constipation, headache, abdominal pain or nausea). 


\section{Data extraction}

Two investigators (CJB and ACF) extracted all data independently onto a Microsoft Excel spreadsheet (XP professional edition; Microsoft Corp, Redmond, Washington, USA) as dichotomous outcomes (response or no response to therapy). For all included studies, the following data were also extracted for each trial where available: country of origin, number of centres, criteria used to define IBS, subtype of IBS, proportion of female patients and dose and duration of therapy. Data were extracted as intention-to-treat analyses, with dropouts assumed to be treatment failures (ie, no response to therapy), using the total number of patients randomised to each treatment arm as the denominator, wherever trial reporting allowed. If this was not clear from the original article, we performed an analysis on all patients with reported evaluable data.

\section{Quality assessment and risk of bias}

This was performed at the study level by two investigators independently (CJB and ACF) using the Cochrane risk of bias tool. ${ }^{24}$ Disagreements were resolved by discussion. The method used to generate the randomisation schedule and conceal treatment allocation was recorded, as well as whether blinding was implemented for participants, personnel and outcomes assessment, whether there was evidence of incomplete outcomes data and whether there was evidence of selective reporting of outcomes.

\section{Data synthesis and statistical analysis}

We performed a network meta-analysis using the frequentist model, with the statistical package 'netmeta' (version 0.9-0, https://cran.r-project.org/web/packages/netmeta/index.html) in $\mathrm{R}$ (V.3.4.2). This was reported according to the Preferred Reporting Items for Systematic Reviews and Meta-Analyses extension statement for network meta-analyses, ${ }^{25}$ in order to explore indirect treatment comparisons of the efficacy and safety of each medication. Network meta-analysis results usually give a more precise estimate, compared with results from standard, pairwise analyses, ${ }^{26}{ }^{27}$ and can also rank treatments to inform clinical decisions. ${ }^{28}$

We examined the symmetry and geometry of the evidence by producing a network plot with node and connection size corresponding to the number of study subjects and number of studies, respectively. We produced comparison-adjusted funnel plots to explore publication bias or other small study effects for all available comparisons versus placebo using Stata V.14. This is a scatterplot of effect size versus precision, measured via the inverse of the SE. Symmetry around the effect estimate line indicates the absence of publication bias or small study effects. ${ }^{29}$ We produced a pooled relative risk (RR) with $95 \%$ CIs to summarise the effect of each comparison tested, using a random effects model as a conservative estimate. We used an RR of failure to achieve each of the endpoints of interest, where if the RR is less than 1 and the $95 \% \mathrm{CI}$ does not cross 1 , there is a significant benefit of the drug over placebo. As there were no direct comparisons between the active treatment groups, we were unable to perform consistency modelling to check the correlation between direct and indirect evidence. ${ }^{30}$

Global statistical heterogeneity across all comparisons was assessed using the $\mathrm{I}^{2}$ measure from the 'netmeta' statistical package. The $\mathrm{I}^{2}$ measure ranges between $0 \%$ and $100 \%$. Values of $25 \%-49 \%, 50 \%-74 \%$ and $\geq 75 \%$ are typically considered low, moderate and high levels of heterogeneity, respectively. ${ }^{31}$ We ranked treatments according to their P-score, which is a value between 0 and 1 . Higher scores indicate a greater probability of the treatment being ranked as best, ${ }^{32}$ but the magnitude of the $\mathrm{p}$ score should be considered, as well as the treatment rank. As the mean value of the P-score is always 0.5 , if individual treatments cluster around this value, they are likely to be of similar efficacy. However, when interpreting the results, it is also important to take the RR and corresponding 95\% CIs for each comparison into account, rather than relying on rankings alone. ${ }^{33}$ In our primary analysis, we pooled data for the FDA-recommended composite endpoint to define treatment response for all included RCTs that reported these data. We also performed analyses to assess the safety of each medication, including overall numbers of adverse events, and number of adverse events leading to study withdrawal, as well as individual adverse events.

The relative efficacies and safeties of therapies for all outcomes were compared using the 'mvmeta' commands in Stata and a random effects model. Treatments were ranked according to their surface under the cumulative ranking curve value, which is comparable with the P-score used in the frequentist model of our primary analyses. ${ }^{32}$

\section{RESULTS}

The search strategy generated 1879 citations, 58 of which appeared to be relevant and were retrieved for further assessment (online supplementary figure 1). Of these, 40 were excluded for various reasons, leaving 18 eligible articles reporting on 18 separate trials, which contained a total of 9844 patients. ${ }^{17-2034-47}$ All trials were fully published, in English, with the exception of one RCT of eluxadoline, identified in abstract form. ${ }^{47}$ There were seven RCTs of alosetron (1951 patients alosetron, 1583 placebo), ${ }^{18}{ }^{34-39}$ five trials of ramosetron (1015 patients ramosetron, 913 placebo), ${ }^{19} 40-43$ two RCTs of rifaximin (625 patients rifaximin, 635 placebo), reported in one article, ${ }^{17}$ and four RCTs of eluxadoline (1967 patients eluxadoline, 1155 placebo), reported in three articles. ${ }^{204477}$ A further two articles were also included because together they provided supplementary data, ${ }^{45}$ reporting efficacy according to FDA-recommended endpoints for alosetron in three phase III RCTs. ${ }^{18} 3439$ These two articles restricted their analyses to female patients who met criteria for severe IBS-D. In addition, the rifaximin trials did not report raw data for many of our analyses of interest in the original article, ${ }^{17}$ but we obtained these data from the pharmaceutical company.

Agreement between investigators for trial eligibility was excellent (kappa statistic $=0.80)$. Detailed characteristics of individual RCTs are provided in table 1. Risk of bias for all included trials is reported in online supplementary table 2. Ten trials, reported in eight articles, were at low risk of bias. ${ }^{17-203942-44}$ No trials made head-to-head comparisons of one drug versus another, meaning that direct evidence was only available in comparison with placebo. As a result, active medications could only be compared with each other using an indirect evidence meta-analysis.

\section{Efficacy}

Failure to achieve the FDA-recommended endpoint to define treatment response

Ten RCTs, reported in seven separate articles, provided dichotomous data for failure to achieve the FDA-recommended composite endpoint at 12 weeks, based on an improvement in abdominal pain and stool consistency. ${ }^{17} 192044-47$ Two of 
Table 1 Characteristics of randomised controlled trials of pharmacological therapies versus placebo in IBS-D or IBS-M

\begin{tabular}{|c|c|c|c|c|c|}
\hline Study & $\begin{array}{l}\text { Country and } \\
\text { number of centres }\end{array}$ & $\begin{array}{l}\text { Diagnostic criteria used } \\
\text { for IBS and subtypes of } \\
\text { IBS recruited }\end{array}$ & $\begin{array}{l}\text { Primary endpoint used to define symptom } \\
\text { improvement following therapy by the } \\
\text { original investigators }\end{array}$ & $\begin{array}{l}\text { Number of } \\
\text { patients } \\
\text { (\% female) }\end{array}$ & $\begin{array}{l}\text { Number of patients assigned to } \\
\text { active drug, dosage, schedule and } \\
\text { duration of therapy }\end{array}$ \\
\hline Camilleri et $a l^{35}$ & $\begin{array}{l}\text { Multinational, } 68 \\
\text { sites. }\end{array}$ & $\begin{array}{l}\text { Rome I criteria, } 100 \% \\
\text { IBS-D or IBS-M. }\end{array}$ & $\begin{array}{l}\text { Adequate relief of pain and discomfort for } \geq 6 \text { of } \\
\text { the } 12 \text { weeks of therapy. }\end{array}$ & 152 (44.1). & $\begin{array}{l}72 \text { patients received alosetron } 1 \mathrm{mg} \\
\text { twice daily for } 12 \text { weeks. }\end{array}$ \\
\hline Camilleri et $a l^{18}$ & USA, 119 sites. & $\begin{array}{l}\text { Rome I criteria, } 70.8 \% \\
\text { IBS-D, } 27.8 \% \text { IBS-M. }\end{array}$ & $\begin{array}{l}\text { Adequate relief of IBS pain and discomfort } \\
\text { for } \geq 2 \text { weeks per month for each of } 3 \text { months. }\end{array}$ & $647(100)$ & $\begin{array}{l}324 \text { patients received alosetron } 1 \mathrm{mg} \\
\text { twice daily for } 12 \text { weeks. }\end{array}$ \\
\hline Camilleri et $a P^{34}$ & USA, 104 sites. & $\begin{array}{l}\text { Rome I criteria, } 71.2 \% \\
\text { IBS-D, } 27.0 \% \text { IBS-M. }\end{array}$ & $\begin{array}{l}\text { Adequate relief of IBS pain and discomfort } \\
\text { for } \geq 2 \text { weeks per month for each of } 3 \text { months. }\end{array}$ & $626(100)$ & $\begin{array}{l}309 \text { patients received alosetron } 1 \mathrm{mg} \\
\text { twice daily for } 12 \text { weeks. }\end{array}$ \\
\hline Lembo et $a l^{38}$ & USA, 180 sites. & $\begin{array}{l}\text { Rome II criteria, } 97.8 \% \\
\text { IBS-D, } 2.2 \% \text { IBS-M. }\end{array}$ & $\begin{array}{l}\text { Substantial or moderate improvement in global } \\
\text { IBS symptoms over the last } 4 \text { weeks of therapy. }\end{array}$ & $801(100)$ & $\begin{array}{l}532 \text { patients received alosetron } 1 \mathrm{mg} \\
\text { twice daily for } 12 \text { weeks. }\end{array}$ \\
\hline Chey et $a l^{36}$ & $\begin{array}{l}\text { Multinational, } 138 \\
\text { sites. }\end{array}$ & $\begin{array}{l}\text { Rome I criteria, } 100 \% \\
\text { IBS-D. } \dagger\end{array}$ & $\begin{array}{l}\text { Weekly adequate relief of IBS pain and discomfort } \\
\text { at week } 48 \text { of treatment. } \neq\end{array}$ & $569(100)$ & $\begin{array}{l}279 \text { patients received alosetron } 1 \mathrm{mg} \\
\text { twice daily for } 48 \text { weeks. }\end{array}$ \\
\hline Chang et $a l^{37}$ & $\begin{array}{l}\text { USA and Canada, } \\
186 \text { sites. }\end{array}$ & $\begin{array}{l}\text { Rome I criteria, } 100 \% \\
\text { IBS-D. }\end{array}$ & $\begin{array}{l}\text { Adequate relief of IBS pain and discomfort for } \\
\text { weeks 5-12 of treatment. }\end{array}$ & $386(0)$ & $\begin{array}{l}127 \text { patients received alosetron } 0.5 \mathrm{mg} \\
\text { twice daily and } 131 \text { received alosetron } \\
1 \mathrm{mg} \text { twice daily for } 12 \text { weeks. }\end{array}$ \\
\hline Krause et $a l^{39}$ & $\begin{array}{l}\text { USA, number of sites } \\
\text { not reported. }\end{array}$ & $\begin{array}{l}\text { Rome II criteria, } 100 \% \\
\text { IBS-D. }\end{array}$ & $\begin{array}{l}\text { Moderate or substantial improvement in global } \\
\text { IBS symptoms over the last } 4 \text { weeks of therapy. }\end{array}$ & 353 (100). & $\begin{array}{l}177 \text { patients received alosetron } 1 \mathrm{mg} \\
\text { twice daily for } 12 \text { weeks. }\end{array}$ \\
\hline Matsueda et al ${ }^{41}$ & $\begin{array}{l}\text { Japan, number of } \\
\text { sites not reported. }\end{array}$ & $\begin{array}{l}\text { Rome II criteria, } 100 \% \\
\text { IBS-D. }\end{array}$ & $\begin{array}{l}\text { Complete or considerable relief of global IBS } \\
\text { symptoms for } \geq 2 \text { of the last } 4 \text { weeks of therapy. }\end{array}$ & 212 (27.3). & $\begin{array}{l}103 \text { patients received ramosetron } 5 \mu \mathrm{g} \\
\text { once daily for } 12 \text { weeks. }\end{array}$ \\
\hline $\begin{array}{l}\text { Matsueda et al } \\
\text { NCT00189696 }\end{array}$ & $\begin{array}{l}\text { Japan, number of } \\
\text { sites not reported. }\end{array}$ & $\begin{array}{l}\text { Rome II criteria, } 100 \% \\
\text { IBS-D. }\end{array}$ & $\begin{array}{l}\text { Complete or considerable relief of global IBS } \\
\text { symptoms for } \geq 2 \text { of the last } 4 \text { weeks of therapy. }\end{array}$ & 539 (17.9). & $\begin{array}{l}270 \text { patients received ramosetron } 5 \mu \mathrm{g} \\
\text { once daily for } 12 \text { weeks. }\end{array}$ \\
\hline $\begin{array}{l}\text { Fukudo et al } \\
\text { NCT01225237 }\end{array}$ & Japan, 52 sites. & $\begin{array}{l}\text { Rome III criteria, } 100 \% \\
\text { IBS-D. }\end{array}$ & $\begin{array}{l}\text { A weekly mean BSFS score of } \geq 3 \text { to } \leq 5 \text { and a } \\
\text { decrease of } \geq 1 \text { point in mean BSFS score from } \\
\text { baseline for } \geq 2 \text { of the first } 4 \text { weeks of therapy. } \neq\end{array}$ & $296(0)$. & $\begin{array}{l}147 \text { patients received ramosetron } 5 \mu \mathrm{g} \\
\text { once daily for } 12 \text { weeks. }\end{array}$ \\
\hline $\begin{array}{l}\text { Fukudo et al } \\
\text { NCT01870895 }\end{array}$ & Japan, 70 sites. & $\begin{array}{l}\text { Rome III criteria, } 100 \% \\
\text { IBS-D. }\end{array}$ & $\begin{array}{l}\text { Complete or considerable relief of global IBS } \\
\text { symptoms for } \geq 2 \text { of the last } 4 \text { weeks of therapy. }\end{array}$ & $576(100)$ & $\begin{array}{l}292 \text { patients received ramosetron } 2.5 \mu \mathrm{g} \\
\text { once daily for } 12 \text { weeks. }\end{array}$ \\
\hline $\begin{array}{l}\text { Fukudo et al } \\
\text { NCT01274000 }\end{array}$ & Japan, 61 sites. & $\begin{array}{l}\text { Rome III criteria, } 100 \% \\
\text { IBS-D. }\end{array}$ & $\begin{array}{l}\text { Complete or considerable relief of global IBS } \\
\text { symptoms for } \geq 2 \text { of the last } 4 \text { weeks of therapy. }\end{array}$ & 305 (100). & $\begin{array}{l}104 \text { and } 99 \text { patients received } \\
\text { ramosetron } 2.5 \mu \mathrm{g} \text { or } 5 \mu \mathrm{g} \text { once daily, } \\
\text { respectively, for } 12 \text { weeks. }\end{array}$ \\
\hline $\begin{array}{l}\text { Pimentel et al } \\
\text { (Target 1) } \\
\text { NCT00731679 }\end{array}$ & $\begin{array}{l}\text { USA and Canada, } \\
179 \text { sites. }\end{array}$ & $\begin{array}{l}\text { Rome II criteria, } 100 \% \\
\text { IBS-D or IBS-M. }\end{array}$ & $\begin{array}{l}\text { Adequate relief of global IBS symptoms for } \geq 2 \text { of } \\
\text { the first } 4 \text { weeks after therapy. } \neq\end{array}$ & 623 (73.4). & $\begin{array}{l}309 \text { patients received rifaximin } 550 \mathrm{mg} \\
\text { three times daily for } 2 \text { weeks. }\end{array}$ \\
\hline $\begin{array}{l}\text { Pimentel et al } \\
\text { (Target 2) } \\
\text { NCT00724126 }\end{array}$ & $\begin{array}{l}\text { USA and Canada, } \\
179 \text { sites. }\end{array}$ & $\begin{array}{l}\text { Rome II criteria, } 100 \% \\
\text { IBS-D or IBS-M. }\end{array}$ & $\begin{array}{l}\text { Adequate relief of global IBS symptoms for } \geq 2 \text { of } \\
\text { the first } 4 \text { weeks after therapy. } \neq\end{array}$ & 637 (71.2) & $\begin{array}{l}316 \text { patients received rifaximin } 550 \mathrm{mg} \\
\text { threee times daily for } 2 \text { weeks. }\end{array}$ \\
\hline $\begin{array}{l}\text { Dove et al } \\
\text { NCT01130272 }\end{array}$ & USA, 263 sites. & $\begin{array}{l}\text { Rome III criteria, } 100 \% \\
\text { IBS-D. }\end{array}$ & $\begin{array}{l}\geq 30 \% \text { reduction in worst abdominal pain score } \\
\text { and at least two points, and a daily BSFS score of } \\
3 \text { or } 4 \text { on } \geq 66 \% \text { of daily diary entries at week } 4 . \ddagger\end{array}$ & 348 (69.3). & $\begin{array}{l}176 \text { patients received eluxadoline } \\
100 \text { mg twice daily for } 12 \text { weeks. }\end{array}$ \\
\hline $\begin{array}{l}\text { Lembo et al } \\
\text { (IBS-3001) } \\
\text { NCT01553591 }\end{array}$ & $\begin{array}{l}\text { USA, Canada and } \\
\text { UK, } 295 \text { sites. }\end{array}$ & $\begin{array}{l}\text { Rome III criteria, } 100 \% \\
\text { IBS-D. }\end{array}$ & $\begin{array}{l}\geq 30 \% \text { reduction in worst abdominal pain score } \\
\text { on } \geq 50 \% \text { of days and, on the same days, a daily } \\
\text { BSFS score of }<5 \text { at week } 12 \text {. }\end{array}$ & 1282 (65.4). & $\begin{array}{l}429 \text { and } 426 \text { patients received } \\
\text { eluxadoline } 75 \mathrm{mg} \text { or } 100 \mathrm{mg} \text { twice daily, } \\
\text { respectively, for } 26 \text { weeks. }\end{array}$ \\
\hline $\begin{array}{l}\text { Lembo et al } \\
\text { (IBS-3002) } \\
\text { NCT01553747 }\end{array}$ & $\begin{array}{l}\text { USA, Canada and } \\
\text { UK, } 261 \text { sites. }\end{array}$ & $\begin{array}{l}\text { Rome III criteria, } 100 \% \\
\text { IBS-D. }\end{array}$ & $\begin{array}{l}\geq 30 \% \text { reduction in worst abdominal pain score } \\
\text { on } \geq 50 \% \text { of days and, on the same days, a daily } \\
\text { BSFS score of }<5 \text { at week } 12 \text {. }\end{array}$ & $1146(67.0)$ & $\begin{array}{l}381 \text { and } 383 \text { patients received } \\
\text { eluxadoline } 75 \mathrm{mg} \text { or } 100 \mathrm{mg} \text { twice daily, } \\
\text { respectively, for } 26 \text { weeks. }\end{array}$ \\
\hline $\begin{array}{l}\text { Brenner (RELIEF) } \\
\text { NCT02959983 }^{47}\end{array}$ & $\begin{array}{l}\text { USA and Canada, } \\
\text { number of sites not } \\
\text { reported. }\end{array}$ & $\begin{array}{l}\text { Rome III criteria, } 100 \% \\
\text { IBS-D. }\end{array}$ & $\begin{array}{l}\geq 40 \% \text { reduction in worst abdominal pain score } \\
\text { on } \geq 50 \% \text { of days and a daily BSFS score of }<5 \text { at } \\
\text { week } 12 \text {. }\end{array}$ & 346 (69.9). & $\begin{array}{l}172 \text { patients received eluxadoline } \\
100 \text { mg twice daily for } 12 \text { weeks. }\end{array}$ \\
\hline
\end{tabular}

†Also recruited patients with IBS-M, but data were only extractable for those with IBS-D at 12 weeks.

\#Efficacy data were extracted at 12 weeks for the purpose of this analysis.

BSFS, Bristol Stool Form Scale; IBS-D, IBS with diarrhoea; IBS-M, IBS with mixed stool pattern.

the articles, between them, provided sufficient information to enable a post hoc analysis of three of the phase III RCTs of alosetron, which reported efficacy according to FDA-recommended endpoints only in women with severe IBS-D. ${ }^{45} 46$

These 10 trials included a total of 5517 patients, 3156 of whom were randomised to active treatment and 2361 to placebo. The network plot is provided in online supplementary figure 2. When data were pooled, there was no global statistical heterogeneity $\left(\mathrm{I}^{2}=2.3 \%\right)$ and no evidence of publication bias, or other small study effects (online supplementary figure 3). All treatments were significantly more effective than placebo, but alosetron $1 \mathrm{mg}$ twice daily was ranked as the most effective (P-score 0.97) in three RCTs (RR $0.69 ; 95 \%$ CI 0.60 to 0.80 ) (figure 1). This means that the probability of alosetron being the most effective when all treatments, including placebo, were compared with each other was 97\%. After indirect comparison of active treatments, significant differences were seen with alosetron $1 \mathrm{mg}$ twice daily, compared with all other treatments except ramosetron $2.5 \mu \mathrm{g}$ once daily (table 2 ).

\section{Failure to achieve a global IBS symptom response}

When dichotomous data were pooled for failure to achieve relief of global symptoms of IBS, there were $13 \mathrm{RCTs}$, reported in 11 articles, recruiting 7464 patients. ${ }^{17} 192038-4447$ Of these, 4316 were randomised to active treatment and 3148 to placebo. When data were pooled, there was moderate global statistical heterogeneity $\left(\mathrm{I}^{2}=67.4 \%\right)$, which was driven by the trials of alosetron $1 \mathrm{mg}$ twice daily. The comparison adjusted funnel plot for publication bias, or other small study effects, showed no asymmetry 


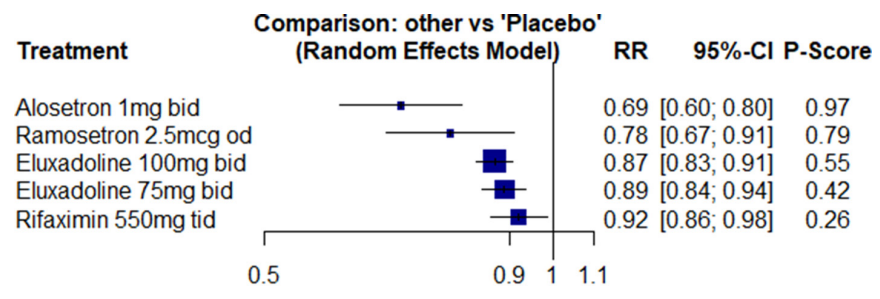

Favours experimental Favours placebo

Figure 1 Forest plot of the indirect evidence for failure to achieve the FDA-recommended endpoint to define treatment response. Note: the P-score is the probability of each treatment being ranked as best in the network analysis. A higher score equates to a greater probability of being ranked first. RR, relative risk.

around the zero line (online supplementary figure 4). All treatments were significantly more effective than placebo, with the exception of rifaximin $550 \mathrm{mg}$ three times daily, but alosetron $1 \mathrm{mg}$ twice daily was ranked as the most effective (P-score 0.96) in two RCTs (RR 0.62; 95\% CI 0.51 to 0.76) (figure 2). After indirect comparison of active treatments, significant differences were seen with alosetron $1 \mathrm{mg}$ twice daily compared with rifaximin $550 \mathrm{mg}$ three times daily (table 3 ).

Failure to achieve an abdominal pain response

There were 17 trials recruiting 9043 patients, reported in 15 separate articles, ${ }^{17-2034-3739-4447}$ that reported dichotomous data for failure to achieve an abdominal pain response. There were 5026 patients assigned to active therapy and 4017 allocated to placebo. When data were pooled, there was no global statistical heterogeneity $\left(\mathrm{I}^{2}=0 \%\right)$ and no evidence of publication bias, or other small study effects (online supplementary figure 5). Ramosetron $2.5 \mu \mathrm{g}$ once daily, ramosetron $5 \mu \mathrm{g}$ once daily, alosetron $1 \mathrm{mg}$ twice daily and eluxadoline $100 \mathrm{mg}$ twice daily were all significantly more effective than placebo. Overall, ramosetron $2.5 \mu \mathrm{g}$ once daily was ranked as the most effective treatment (P-score 0.94) in two RCTs (RR $0.75 ; 95 \%$ CI 0.65 to 0.85 ) (figure 3 ). On indirect comparison of active treatments, significant differences were seen with ramosetron $2.5 \mu \mathrm{g}$ once daily compared with eluxadoline $75 \mathrm{mg}$ twice daily, eluxadoline $100 \mathrm{mg}$ twice daily and rifaximin $550 \mathrm{mg}$ three times daily, as well as for ramosetron $5 \mu \mathrm{g}$ once daily compared with eluxadoline $75 \mathrm{mg}$ twice daily and rifaximin $550 \mathrm{mg}$ three times daily. Significant differences were also seen for alosetron $1 \mathrm{mg}$ twice daily compared with eluxadoline $75 \mathrm{mg}$ twice daily and rifaximin $550 \mathrm{mg}$ three times daily (online supplementary table 3).

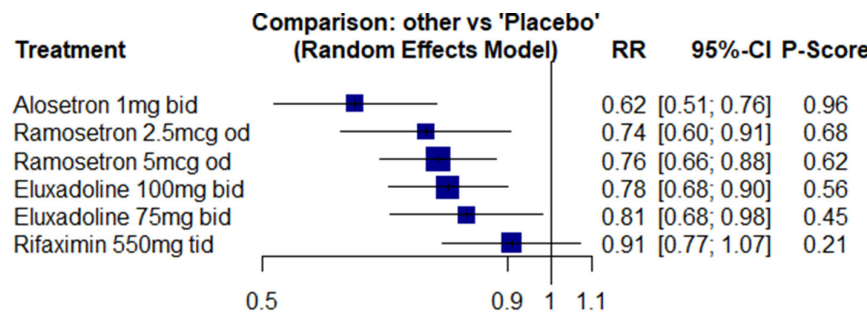

Favours experimental Favours placebo

Figure 2 Forest plot of the indirect evidence for failure to achieve a global IBS symptom response. Note: the P-score is the probability of each treatment being ranked as best in the network analysis. A higher score equates to a greater probability of being ranked first. RR, relative risk.

\section{Failure to achieve a stool consistency response}

Twelve RCTs reported dichotomous data for failure to achieve a stool consistency response, and these were reported in 10 separate articles and included 6663 patients. ${ }^{17} 192039-4447$ There were 3784 patients assigned to active therapy and 2879 to placebo. When data were pooled, there was no global statistical heterogeneity $\left(\mathrm{I}^{2}=18.4 \%\right)$. The comparison adjusted funnel plot for publication bias, or other small study effects, showed no asymmetry around the zero line (online supplementary figure 6). All treatments were significantly more effective than placebo, but alosetron $1 \mathrm{mg}$ twice daily ranked as the most effective treatment (P-score 0.93) although in only one RCT (RR 0.70; 95\% CI 0.60 to 0.81 ) (figure 4). After indirect comparison of active treatments, significant differences were seen with alosetron $1 \mathrm{mg}$ twice daily, compared with eluxadoline $75 \mathrm{mg}$ twice daily and eluxadoline $100 \mathrm{mg}$ twice daily (online supplementary table 4).

\section{Safety}

Sixteen trials, recruiting 9134 patients and reported in 14 articles, ${ }^{17-20} 3437-4447$ provided data for overall adverse events. There was moderate global statistical heterogeneity $\left(\mathrm{I}^{2}=64.2 \%\right)$, but no evidence of publication bias, or other small study effects (online supplementary figure 7). Heterogeneity was driven by the trials of alosetron $1 \mathrm{mg}$ twice daily and ramosetron $5 \mu \mathrm{g}$ once daily. When comparing pooled overall adverse events, alosetron $1 \mathrm{mg}$ twice daily (five RCTs, RR=1.24; 95\% CI 1.09 to 1.41) and ramosetron $2.5 \mu \mathrm{g}$ once daily (two $\mathrm{RCTs}, \mathrm{RR}=1.27$; $95 \%$ CI 1.01 to 1.60 ) were associated with a significant increase in overall adverse events, compared with placebo (online supplementary figure 8). When ranked using a P-score, rifaximin $550 \mathrm{mg}$ three times daily was the best, and ramosetron $2.5 \mu \mathrm{g}$ once daily was the worst, in terms of overall adverse events

\begin{tabular}{|c|c|c|c|c|c|}
\hline \multicolumn{6}{|l|}{$\begin{array}{l}\text { Alosetron } 1 \mathrm{mg} \text { twice } \\
\text { daily }\end{array}$} \\
\hline 0.89 (0.72 to 1.10$)$ & Ramosetron $2.5 \mu \mathrm{g}$ once daily & & & & \\
\hline 0.80 (0.69 to 0.93$)$ & 0.90 (0.77 to 1.05$)$ & Eluxadoline $100 \mathrm{mg}$ twice daily & & & \\
\hline $0.78(0.67$ to 0.91$)$ & 0.88 (0.75 to 1.03$)$ & $0.98(0.91$ to 1.05$)$ & Eluxadoline $75 \mathrm{mg}$ twice daily & & \\
\hline 0.75 (0.64 to 0.89$)$ & 0.85 (0.72 to 1.00$)$ & 0.94 (0.87 to 1.02 ) & 0.97 (0.89 to 1.05$)$ & $\begin{array}{l}\text { Rifaximin } 550 \mathrm{mg} \\
\text { twice daily }\end{array}$ & \\
\hline 0.69 (0.60 to 0.80$)$ & 0.78 (0.67 to 0.91$)$ & 0.87 (0.83 to 0.91$)$ & 0.89 (0.84 to 0.94$)$ & 0.92 (0.86 to 0.98$)$ & Placebo \\
\hline
\end{tabular}

Relative risk with $95 \% \mathrm{Cl}$ in parentheses. Comparisons, column versus row, should be read from left to right and are ordered relative to their overall efficacy. The treatment in the top left position is ranked as best after the network meta-analysis of indirect effects.

Boxes shaded green denote a statistically significant difference. 
Table 3 League table for failure to achieve a global IBS symptom response

\begin{tabular}{|c|c|c|c|c|c|c|}
\hline \multicolumn{7}{|l|}{$\begin{array}{l}\text { Alosetron } 1 \mathrm{mg} \\
\text { twice daily }\end{array}$} \\
\hline 0.84 (0.63 to 1.12 ) & $\begin{array}{l}\text { Ramosetron } 2.5 \mu \mathrm{g} \\
\text { once daily }\end{array}$ & & & & & \\
\hline 0.82 (0.65 to 1.04 ) & 0.97 (0.76 to 1.24$)$ & $\begin{array}{l}\text { Ramosetron } 5 \mu \text { once } \\
\text { daily }\end{array}$ & & & & \\
\hline 0.80 (0.63 to 1.02 ) & 0.95 (0.74 to 1.22 ) & 0.98 (0.80 to 1.19 ) & $\begin{array}{l}\text { Eluxadoline } 100 \mathrm{mg} \\
\text { twice daily }\end{array}$ & & & \\
\hline 0.77 (0.59 to 1.00$)$ & 0.91 (0.69 to 1.19 ) & 0.93 (0.74 to 1.18 ) & 0.96 (0.76 to 1.21$)$ & $\begin{array}{l}\text { Eluxadoline } 75 \mathrm{mg} \\
\text { twice daily }\end{array}$ & & \\
\hline 0.69 (0.53 to 0.89 ) & 0.81 (0.63 to 1.06 ) & 0.84 (0.68 to 1.04 ) & 0.86 (0.69 to 1.07 ) & 0.90 (0.70 to 1.15$)$ & $\begin{array}{l}\text { Rifaximin } 550 \mathrm{mg} \text { three } \\
\text { times daily }\end{array}$ & \\
\hline 0.62 (0.51 to 0.76$)$ & 0.74 (0.60 to 0.91$)$ & 0.76 (0.66 to 0.88$)$ & 0.78 (0.68 to 0.90$)$ & 0.81 (0.68 to 0.98$)$ & 0.91 (0.77 to 1.07 ) & Placebo \\
\hline
\end{tabular}

Relative risk with $95 \% \mathrm{Cls}$ in parentheses. Comparisons, column versus row, should be read from left to right and are ordered relative to their overall efficacy. The treatment in the top left position is ranked as best after the network meta-analysis of indirect effects.

Boxes shaded green denote a statistically significant difference.

(P-scores 0.80 and 0.18 , respectively). Indirect comparison of active treatments revealed no significant differences between individual drugs and dosages.

Adverse events leading to dropout were provided by 15 trials and were reported in 13 papers. ${ }^{17} 1920343538-4447$ Eluxadoline $75 \mathrm{mg}$ twice daily (two RCTs, RR=1.88; 95\% CI 1.25 to 2.81), eluxadoline $100 \mathrm{mg}$ twice daily (four $\mathrm{RCTs}, \mathrm{RR}=1.88$; $95 \%$ CI 1.31 to 2.70 ) and alosetron $1 \mathrm{mg}$ twice daily (four RCTs, $\mathrm{RR}=1.97$; $95 \% \mathrm{CI} 1.48$ to 2.63 ) were all associated with significantly higher trial dropout rates due to adverse events, compared with placebo. When ranked using a P-score, ramosetron $2.5 \mu \mathrm{g}$ once daily was the best, and alosetron $1 \mathrm{mg}$ twice daily was the worst, in terms of adverse events leading to dropout (P-scores 0.92 and 0.16 , respectively). On indirect comparison of active treatments, significant differences were seen with ramosetron $2.5 \mu \mathrm{g}$ once daily compared with eluxadoline $100 \mathrm{mg}$ twice daily, eluxadoline $75 \mathrm{mg}$ twice daily and alosetron $1 \mathrm{mg}$ twice daily. Individual adverse events data are provided in the online supplementary materials.

\section{DISCUSSION}

It is widely accepted that the licenced pharmacological therapies studied in this systematic review and network meta-analysis are more effective than placebo for the treatment of IBS-D and IBS-M. Using the FDA-recommended composite endpoint, although all drugs were more effective than placebo, alosetron $1 \mathrm{mg}$ twice daily ranked first, according to the available evidence. The probability of alosetron being superior to another competing treatment, according to this endpoint, was $97 \%$, which exceeds

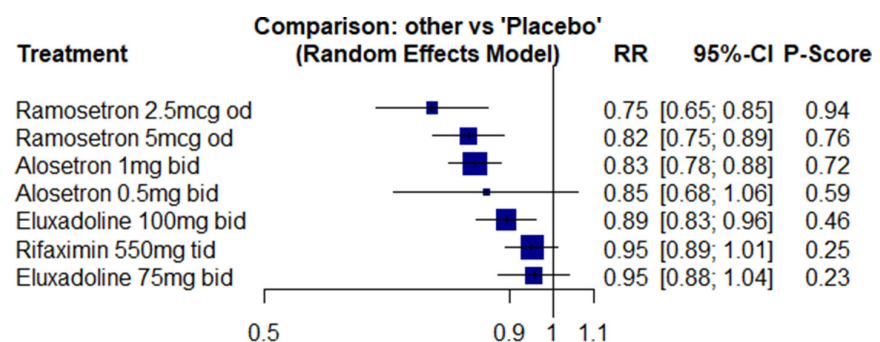

Favours experimental Favours placebo

Figure 3 Forest plot of the indirect evidence for failure to achieve an abdominal pain response. Note: the P-score is the probability of each treatment being ranked as best in the network analysis. A higher score equates to a greater probability of being ranked first. RR, relative risk. the $90 \%-95 \%$ threshold that the available literature suggests is desirable. ${ }^{32}$ Alosetron $1 \mathrm{mg}$ twice daily continued to be ranked first when efficacy was assessed in terms of improvement in global IBS symptoms and stool consistency. Ramosetron $2.5 \mu \mathrm{g}$ and $5 \mu \mathrm{g}$ once daily were ranked first and second when effect on abdominal pain was studied. Rifaximin $550 \mathrm{mg}$ three times daily was no better than placebo for global IBS symptoms, and rifaximin $550 \mathrm{mg}$ three times daily, alosetron $0.5 \mathrm{mg}$ twice daily and eluxadoline $75 \mathrm{mg}$ twice daily were no more effective than placebo for abdominal pain. Alosetron $1 \mathrm{mg}$ twice daily and ramosetron $2.5 \mu \mathrm{g}$ once daily were both associated with a significant increase in overall adverse events, compared with placebo. Constipation was significantly more likely with all drugs, except rifaximin $550 \mathrm{mg}$ three times daily, which ranked first for safety overall. The latter observation may be consistent with the observation that rifaximin may actually accelerate colonic transit ${ }^{48}$ and improve symptoms of IBS-C. ${ }^{49}$ Finally, more patients reported abdominal pain as an adverse event with eluxadoline and alosetron than with placebo, although whether this is due to the fluctuating natural history of IBS, an associated feature of drug-induced constipation or a specific adverse event associated with both drugs is unclear.

We undertook a contemporaneous and exhaustive literature search. This was conducted independently by two reviewers and included searching conference proceedings, the 'grey' literature and ClinicalTrials.gov. Assessment of eligibility and data extraction was also performed independently and in duplicate. We subsequently contacted the authors of two trials of rifaximin $^{17}$ and one trial of eluxadoline, ${ }^{47}$ in order to obtain the necessary data for our analyses, as these were not available in the

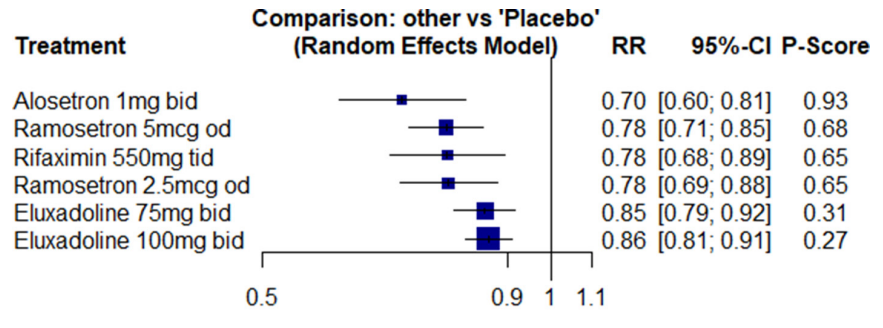

Favours experimental Favours placebo

Figure 4 Forest plot of the indirect evidence for failure to achieve a stool consistency response. Note: the P-score is the probability of each treatment being ranked as best in the network analysis. A higher score equates to a greater probability of being ranked first. RR, relative risk. 
original papers. This inclusive approach enabled us to analyse data from 18 RCTs of pharmacological therapies for IBS-D and IBS-M, recruiting almost 10000 patients, with data extracted at 12 weeks for all endpoints. We used an intention-to-treat analysis and pooled data using a random effects model to minimise the risk that the efficacy of the drugs studied would be overestimated. Finally, we extracted and pooled adverse events, where reported, in order to provide summary safety data.

We did not identify any head-to-head studies of one drug versus another, meaning that all our analyses were based on indirect comparisons, which are not protected by randomisation. This could lead to confounding due to underlying differences between individual RCTs, ${ }^{50}$ although our use of very similar endpoints to define efficacy after 12 weeks of treatment in all trials should minimise this. However, this means that the relative efficacy and safety of these drugs in the longer term are unknown. In addition, 8 of the 18 trials were at unclear risk of bias, ${ }^{34-38} 404147$ which may mean the efficacy of some of the drugs has been overestimated. ${ }^{51}$ It is likely that these deficiencies represent omissions of reporting, rather than true design flaws, given the oversight of national regulatory agencies for many of the included trials. There were moderate levels of global statistical heterogeneity in the analysis using an improvement in global IBS symptoms to define treatment response, and for total adverse events, but no heterogeneity in any of our other analyses. It is important to point out that, as in most trials of pharmacological therapies in IBS, adverse events were not reported according to standardised endpoints, unlike efficacy data, which may mean making comparisons between individual treatments is less valid. Finally, there may have been subtle differences in symptom severity among the populations studied in each of these trials, which mean the results are not directly comparable. However, this should have been minimised, as 16 of the trials used similar combinations of a minimum abdominal pain threshold and a minimum stool consistency threshold, during a run-in period, to confirm eligibility prior to study entry. Among the remaining two RCTs: one did not report these data as it was in abstract form ${ }^{47}$ and one used a minimum urgency threshold. ${ }^{38}$

Ranking of these pharmacological therapies provides useful information to aid clinical decision making, but it is important to acknowledge that not all of these drugs are available in all countries or, indeed, to all patients with IBS-D or IBS-M. Alosetron was withdrawn in the USA because of adverse events, including ischaemic colitis and severe constipation. It was reintroduced, via a risk evaluation and mitigation strategy for women with severe IBS-D. In the first 9 years after reintroduction, 29 cases of probable ischaemic colitis were reported: an incidence of 1 case per 1000 patient-years. ${ }^{52}$ This is similar to the background rate of ischaemic colitis in female patients with IBS, which ranges from 0.40 cases/1000 patient-years to 1.79 cases/1000 patient-years. ${ }^{53}$ Whether alosetron is effective in men with IBS-D is unclear, as only one RCT recruited solely men, ${ }^{37}$ and participants in the remaining trials were either predominantly, or exclusively, women. However, cilansetron, another 5-HT receptor antagonist, appeared to be effective in both men and women with IBS-D. ${ }^{21}$ Although ramosetron can be prescribed for men with IBS-D, as well as women, it is only licenced in Japan and some other South, and Southeast, Asian countries, at a dose of $2.5 \mu \mathrm{g}$ once daily in women and $5 \mu \mathrm{g}$ once daily in men. However, three of the trials conducted using $5 \mu \mathrm{g}$ once daily recruited women. ${ }^{40}{ }^{41} 43$ If this dose was either not as effective or less well-tolerated in women, one would have expected this to have diluted efficacy, or led to more adverse events, yet $5 \mu \mathrm{g}$ once daily was ranked second for its effect on both abdominal pain and stool consistency and was by no means the lowest ranked drug in terms of safety.

Although both alosetron and ramosetron appeared to perform the best in this network meta-analysis, many patients with IBS will be unable to access these drugs. Two recent RCTs of ondansetron, another $5-\mathrm{HT}_{3}$ receptor antagonist, which is widely available and has a robust safety profile, suggest that this drug is also of benefit in IBS. ${ }^{5455}$ Neither of these trials were eligible for inclusion in our network, as the drug is not licenced for IBS, one trial was a cross-over RCT with a treatment duration of 10 weeks, ${ }^{54}$ and the other was a parallel arm trial of only 8 weeks' duration. ${ }^{55}$ However, a 12 -week trial is in progress in the UK. ${ }^{56}$ Another issue is that all of the RCTs of ramosetron were conducted in Japan, and the majority of the trials of alosetron, eluxadoline and rifaximin were conducted in North American populations, so the findings may not be generalisable to individuals with IBS-D or IBS-M in other countries.

Because these studies span the last 20 years of clinical practice, during which time the Rome criteria for IBS have undergone multiple revisions, ${ }^{257-59}$ there are variations between individual trial populations, in terms of how the diagnosis of IBS was determined. The majority of the alosetron trials and the earlier ramosetron RCTs used the Rome I or II criteria, ${ }^{57} 59$ which are arguably less restrictive than the Rome III criteria, ${ }^{58}$ used in later trials of ramosetron and all studies of rifaximin and eluxadoline. However, agreement between these criteria for the diagnosis of IBS is good, ${ }^{60}$ and such differences are mitigated against, to some extent, by our ability to compare all drugs using the standardised FDA-recommended endpoint for trials in IBS-D. It is important to highlight that, because these endpoints had not been agreed at the time some of the earlier drug trials were conducted, the data for alosetron are based entirely on a post hoc analysis of three trials. ${ }^{45}{ }^{46}$ Around $50 \%$ of patients in these trials were absent from the analysis, because they failed to meet the updated FDA-recommended symptom thresholds for inclusion in an IBS treatment trial. This may mean that the efficacy of alosetron has been overestimated for this endpoint, although as only patients with severe IBS-D were included in this analysis, we feel this is unlikely. In addition, the strength of the P-score for alosetron, together with the absence of global statistical heterogeneity, suggests that the treatment ranking we report is likely to be accurate.

All of the drugs considered in this network meta-analysis are likely to be prescribed as second-line therapy, after failure of antidiarrhoeal and anti-spasmodic drugs. It would therefore be important to understand how they perform relative to these first-line therapies, particularly as loperamide is available over the counter in many countries and has evidence of shortterm efficacy for reducing diarrhoea. ${ }^{9}$ Unfortunately, there are few trials examining this issue. One RCT demonstrated that 12 weeks of alosetron $1 \mathrm{mg}$ twice daily was superior to mebeverine $135 \mathrm{mg}$ three times daily, in terms of adequate relief of abdominal pain, in a mixed population of patients with IBS of all subtypes, ${ }^{61}$ but a trial of 4 weeks of ramosetron $5 \mu \mathrm{g}$ once daily versus mebeverine $135 \mathrm{mg}$ three times daily demonstrated no significant differences. ${ }^{62}$

There have also been no head-to-head trials of these drugs against other second-line therapies, such as tricyclic antidepressants. Additionally, there are no RCTs of tricyclic antidepressants or other pharmacological therapies used off-licence for IBS that have been conducted solely in patients with IBS-D or IBS-M over 12 weeks reporting identical endpoints to the ones used in these trials ${ }^{9}$ and that could therefore have been included in this network meta-analysis. Another RCT has compared 24 weeks of alosetron $1 \mathrm{mg}$ twice daily with traditional pharmacotherapy, which in some patients consisted of tricyclic antidepressants, in almost 2000 female 
patients with severe IBS-D. ${ }^{63}$ In this trial, treatment with alosetron $1 \mathrm{mg}$ twice daily resulted in significantly greater relief of global IBS symptoms. There were also significant reductions in number of visits to see a physician for IBS, use of over the counter medications and days of lost work productivity. However, this beneficial effect was accompanied by non-serious constipation, occurring in one-third of patients, compared with constipation in $<1 \%$ of those allocated to traditional pharmacotherapy. Initiating alosetron at a dose of $0.5 \mathrm{mg}$ twice daily, and increasing the dose subsequently if there is inadequate clinical improvement, as is currently recommended, may minimise this. Finally, the two large, phase III trials of eluxadoline have reported efficacy of the drug in a subset of patients who had previously failed loperamide ${ }^{20}$ with similar efficacy demonstrated in this post hoc analysis. ${ }^{8}$ The most recent RCT of eluxadoline we identified had recruited only patients with IBS-D who reported, subjectively, that they had previously failed loperamide, again with similar results. ${ }^{47}$

Given the lack of head-to-head trials, performing a network meta-analysis could be criticised, because all our conclusions are derived from data based on indirect treatment comparisons. However, as we have discussed previously, ${ }^{2264}$ it is unlikely that pharmaceutical companies will ever conduct such studies or even undertake a trial of one of these drugs against an antidiarrhoeal or tricyclic antidepressant. Network meta-analyses circumvent this problem to some extent, allowing credible ranking systems of the likely efficacy and safety of different treatments to be developed, even in the absence of trials making direct comparisons. The results of our study are therefore still likely to be important for both patients and policy makers, in order to help inform treatment decisions for IBS-D and IBS-M.

In summary, although all drugs were superior to placebo, according to the FDA-recommended composite endpoint for trials in IBS, alosetron $1 \mathrm{mg}$ twice daily ranked first in terms of efficacy in our network meta-analysis. It was also the top ranked treatment when either global relief of symptoms or improvement in stool consistency were used to define treatment response, but ramosetron $2.5 \mu \mathrm{g}$ once daily was ranked first in terms of improving abdominal pain. With regard to safety, rifaximin $550 \mathrm{mg}$ three times daily was least likely to cause adverse events and was the only drug that did not significantly increase the risk of constipation. However, it demonstrated relatively poor efficacy across many of the treatment endpoints we studied. Eluxadoline $100 \mathrm{mg}$ twice daily, meanwhile, was significantly better than placebo across all endpoints, but its overall performance was modest. This information will hopefully assist clinicians in choosing a second-line treatment for IBS-D, and to a lesser extent IBS-M, based on the patient's most troublesome symptom, considering both efficacy and safety. Alosetron and ramosetron remain unavailable in many countries. Given the chronic and frequently debilitating nature of IBS, this lack of availability may need to be reconsidered, in order to widen access to potentially effective second-line treatments for those patients with IBS-D or IBS-M when conventional first-line therapies fail.

Correction notice This article has been corrected since it published Online First. The author statement has been added.

Acknowledgements We are grateful to Darren Brenner, Mark Pimentel and Mary Beth Moncrief for providing us with extra data for the RELIEF trial of eluxadoline and the Target 1 and 2 trials of rifaximin.

Contributors Guarantor of the article: ACF is guarantor. Specific author contributions: all authors conceived and drafted the study. ACF and CJB collected all data. CJB, NEB and ACF analysed and interpreted the data. CJB, NEB and ACF drafted the manuscript. All authors commented on drafts of the paper. All authors have approved the final draft of the manuscript.
Funding The authors have not declared a specific grant for this research from any funding agency in the public, commercial or not-for-profit sectors.

Competing interests $M C$ has received research funding from Allergan. DLE has acted as a consultant for Prometheus Laboratories. EMMQ has acted as a consultant to Almirall, Synergy and Salix. PM has received honoraria from Allergan and Salix, and research funding from Allergan. LAH has acted as a consultant for, and received research funding from Takeda, USA, and has acted as a consultant for Pfizer, USA. ACF has acted as a consultant for and received researching funding from Almirall.

Patient consent for publication Not required.

Provenance and peer review Not commissioned; externally peer reviewed.

\section{ORCID iDs}

Michael Camilleri http://orcid.org/0000-0001-6472-7514

Alexander C Ford http://orcid.org/0000-0001-6371-4359

\section{REFERENCES}

1 Lovell RM, Ford AC. Global prevalence of and risk factors for irritable bowel syndrome: a meta-analysis. Clin Gastroenterol Hepatol 2012;10:712-21.

2 Mearin F, Lacy BE, Chang L, et al. Bowel disorders. Gastroenterology 2016;150:1393-407.

3 Everhart JE, Ruhl CE. Burden of digestive diseases in the United States part II: lower gastrointestinal diseases. Gastroenterology 2009;136:741-54.

4 Gralnek IM, Hays RD, Kilbourne A, et al. The impact of irritable bowel syndrome on health-related quality of life. Gastroenterology 2000;119:654-60.

5 Singh P, Staller K, Barshop K, et al. Patients with irritable bowel syndrome-diarrhea have lower disease-specific quality of life than irritable bowel syndrome-constipation. World I Gastroenterol 2015;21:8103-9.

6 Atarodi S, Rafieian S, Whorwell PJ. Faecal incontinence-the hidden scourge of irritable bowel syndrome: a cross-sectional study. BMJ Open Gastroenterol 2014;1:e000002.

7 Buono JL, Carson RT, Flores NM. Health-related quality of life, work productivity, and indirect costs among patients with irritable bowel syndrome with diarrhea. Health Qual Life Outcomes 2017;15:35.

8 Lacy BE, Chey WD, Cash BD, et al. Eluxadoline Efficacy in IBS-D Patients Who Report Prior Loperamide Use. Am J Gastroenterol 2017:112:924-32.

9 Ford AC, Moayyedi P, Chey WD, et al. ACG Task Force on Management of Irritable Bowel Syndrome. American College of Gastroenterology Monograph on Management of Irritable Bowel Syndrome. Am J Gastroenterol 2018;113(Suppl 2):1-18.

10 Ford AC, Lacy BE, Harris LA, et al. Effect of antidepressants and psychological therapies in irritable bowel syndrome: an updated systematic review and metaanalysis. Am J Gastroenterol 2019;114:21-39.

11 Ford AC, Talley NJ, Spiegel BM, et al. Effect of fibre, antispasmodics, and peppermint oil in the treatment of irritable bowel syndrome: systematic review and meta-analysis. BMJ 2008:337:a2313-92.

12 Houghton LA, Foster JM, Whorwell PJ. Alosetron, a 5-HT3 receptor antagonist, delays colonic transit in patients with irritable bowel syndrome and healthy volunteers. Aliment Pharmacol Ther 2000;14:775-82.

13 Min YW, Rhee PL. The clinical potential of ramosetron in the treatment of irritable bowel syndrome with diarrhea (IBS-D). Therap Adv Gastroenterol 2015;8:136-42.

14 Delvaux M, Louvel D, Mamet JP, et al. Effect of alosetron on responses to colonic distension in patients with irritable bowel syndrome. Aliment Pharmacol Ther 1998; 12:849-55

15 Kane JS, Ford AC. Rifaximin for the treatment of diarrhea-predominant irritable bowel syndrome. Expert Rev Gastroenterol Hepatol 2016;10:431-42.

16 Barshop K, Staller K. Eluxadoline in irritable bowel syndrome with diarrhea: rationale, evidence and place in therapy. Ther Adv Chronic Dis 2017:8:153-60.

17 Pimentel M, Lembo A, Chey WD, et al. Rifaximin therapy for patients with irritable bowel syndrome without constipation. N Engl J Med 2011;364:22-32.

18 Camilleri M, Northcutt AR, Kong S, et al. Efficacy and safety of alosetron in women with irritable bowel syndrome: a randomised, placebo-controlled trial. Lancet 2000;355:1035-40.

19 Fukudo S, Kinoshita Y, Okumura T, et al. Ramosetron Reduces Symptoms of Irritable Bowel Syndrome With Diarrhea and Improves Quality of Life in Women. Gastroenterology 2016;150:358-66.

20 Lembo AJ, Lacy BE, Zuckerman MJ, et al. Eluxadoline for Irritable Bowel Syndrome with Diarrhea. N Engl J Med 2016;374:242-53.

21 Ford AC, Brandt L, Young C, et al. Efficacy of 5-HT3 antagonists and 5-HT4 agonists in irritable bowel syndrome: systematic review and meta-analysis. Am I Gastroenterol 2009;104:1831-43

22 Black CJ, Burr NE, Quigley EMM, et al. Efficacy of secretagogues in patients with irritable bowel syndrome with constipation: systematic review and network metaanalysis. Gastroenterology 2018;155:1753-63.

23 Ford AC, Moayyedi P. Meta-analysis: factors affecting placebo response rate in the irritable bowel syndrome. Aliment Pharmacol Ther 2010;32:144-58

24 Higgins JPT, Green S. Cochrane handbook for systematic reviews of interventions: Version 5.1.0. 2009 wwwcochrane-handbookorg. 
25 Hutton B, Salanti G, Caldwell DM, et al. The PRISMA extension statement for reporting of systematic reviews incorporating network meta-analyses of health care interventions: checklist and explanations. Ann Intern Med 2015;162:777-84.

26 Salanti G, Higgins JP, Ades AE, et al. Evaluation of networks of randomized trials. Stat Methods Med Res 2008;17:279-301.

27 Salanti G. Indirect and mixed-treatment comparison, network, or multiple-treatments meta-analysis: many names, many benefits, many concerns for the next generation evidence synthesis tool. Res Synth Methods 2012:3:80-97.

28 Salanti G, Ades AE, loannidis JP. Graphical methods and numerical summaries for presenting results from multiple-treatment meta-analysis: an overview and tutorial. J Clin Epidemiol 2011;64:163-71.

29 Chaimani A, Higgins JP, Mavridis D, et al. Graphical tools for network meta-analysis in STATA. PLOS One 2013:8:e76654.

30 Higgins JP, Jackson D, Barrett JK, et al. Consistency and inconsistency in network meta-analysis: concepts and models for multi-arm studies. Res Synth Methods 2012:3:98-110

31 Higgins JP, Thompson SG, Deeks JJ, et al. Measuring inconsistency in meta-analyses. BMJ 2003;327:557-60.

32 Rücker G, Schwarzer G. Ranking treatments in frequentist network meta-analysis works without resampling methods. BMC Med Res Methodol 2015;15:58.

33 Morton SC, Murad MH, O'Connor E, et al. AHRQ methods for effective health care. Quantitative synthesis-an update. Methods Guide for Effectiveness and Comparative Effectiveness Reviews. Rockville (MD: Agency for Healthcare Research and Quality (US), 2018.

34 Camilleri M, Chey WY, Mayer EA, et al. A randomized controlled clinical trial of the serotonin type 3 receptor antagonist alosetron in women with diarrhea-predominant irritable bowel syndrome. Arch Intern Med 2001;161:1733-40.

35 Camilleri M, Mayer EA, Drossman DA, et al. Improvement in pain and bowel function in female irritable bowel patients with alosetron, a 5-HT3 receptor antagonist. Aliment Pharmacol Ther 1999;13:1149-59.

36 Chey WD, Chey WY, Heath AT, et al. Long-term safety and efficacy of alosetron in women with severe diarrhea-predominant irritable bowel syndrome. Am J Gastroenterol 2004;99:2195-203.

37 Chang L, Ameen VZ, Dukes GE, et al. A dose-ranging, phase II study of the efficacy and safety of alosetron in men with diarrhea-predominant IBS. Am J Gastroenterol 2005;100:115-23

38 Lembo T, Wright RA, Bagby B, et al. Lotronex Investigator Team. Alosetron controls bowel urgency and provides global symptom improvement in women with diarrheapredominant irritable bowel syndrome. Am I Gastroenterol 2001:96:2662-70.

39 Krause R, Ameen V, Gordon SH, et al. A randomized, double-blind, placebo-controlled study to assess efficacy and safety of $0.5 \mathrm{mg}$ and $1 \mathrm{mg}$ alosetron in women with severe diarrhea-predominant IBS. Am J Gastroenterol 2007:102:1709-19.

40 Matsueda K, Harasawa S, Hongo M, et al. A randomized, double-blind, placebocontrolled clinical trial of the effectiveness of the novel serotonin type 3 receptor antagonist ramosetron in both male and female Japanese patients with diarrheapredominant irritable bowel syndrome. Scand I Gastroenterol 2008:43:1202-11.

41 Matsueda K, Harasawa S, Hongo M, et al. A phase II trial of the novel serotonin type 3 receptor antagonist ramosetron in Japanese male and female patients with diarrheapredominant irritable bowel syndrome. Digestion 2008;77:225-35.

42 Fukudo S, Ida M, Akiho H, et al. Effect of ramosetron on stool consistency in male patients with irritable bowel syndrome with diarrhea. Clin Gastroenterol Hepatol 2014:12:953-9

43 Fukudo S, Matsueda K, Haruma K, et al. Optimal dose of ramosetron in female patients with irritable bowel syndrome with diarrhea: A randomized, placebocontrolled phase II study. Neurogastroenterol Motil 2017:29:e13023.

44 Dove LS, Lembo A, Randall CW, et al. Eluxadoline benefits patients with irritable bowel syndrome with diarrhea in a phase 2 study. Gastroenterology 2013;145:329-38
45 Cash BD, Lacy BE, Rao T, et al. Rifaximin and eluxadoline - newly approved treatments for diarrhea-predominant irritable bowel syndrome: what is their role in clinical practice alongside alosetron? Expert Opin Pharmacother 2016;17:311-22.

46 Camilleri M, Krause R, Deveze $S$, et al. Evaluation of alosetron using the new FDA composite endpoint demonstrates strong treatment effect in females with severe irritable bowel syndrome with diarrhea. Am J Gastroenterol 2014; 109:\$535.

47 Brenner D, Gutman C, Jo E. Efficacy and Safety of Eluxadoline in IBS-D Patients Who Report Inadequate Symptom Control With Prior Loperamide Use: A Phase 4, Multicenter, Multinational, Randomized, Placebo-controlled, Double-blinded Study (RELIEF): Presidential Poster Award. Am J Gastroenterol 2018;113(Supplement):S254-5.

48 Acosta A, Camilleri M, Shin A, et al. Effects of rifaximin on transit, permeability, fecal microbiome, and organic acid excretion in irritable bowel syndrome. Clin Trans/ Gastroenterol 2016;7:e173.

49 Pimentel M, Chang C, Chua KS, et al. Antibiotic treatment of constipationpredominant irritable bowel syndrome. Dig Dis Sci 2014:59:1278-85.

50 Cipriani A, Higgins JP, Geddes JR, et al. Conceptual and technical challenges in network meta-analysis. Ann Intern Med 2013;159:130-7.

51 Juni P, Altman DG, Egger M. Assessing the quality of controlled clinical trials. BMJ 2001;323:42-6.

52 Tong K, Nicandro JP, Shringarpure R, et al. A 9-year evaluation of temporal trends in alosetron postmarketing safety under the risk management program. Therap $A d v$ Gastroenterol 2013:6:344-57.

53 Cole JA, Cook SF, Sands BE, et al. Occurrence of colon ischemia in relation to irritable bowel syndrome. Am J Gastroenterol 2004:99:486-91.

54 Garsed K, Chernova J, Hastings M, et al. A randomised trial of ondansetron for the treatment of irritable bowel syndrome with diarrhoea. Gut 2014:63:1617-25.

55 Randomized, double-blind, placebo-controlled phase 2 trial of BEKINDA (ondansetron $12 \mathrm{mg}$ bimodal release tablets) for diarrhea predominant irritable bowel syndrome (IBS-D). https://clinicaltrialsgov/ct2/show/ NCT02757105?term=ondansetron\&cond=|rritable+Bowel+Syndrome\&rank=2.

56 Treatment of irritable bowel syndrome with diarrhoea using titrated ondansetron trial (TRITON). https://clinicaltrialsgov/ct2/show/ NCT03555188?term=ondansetron\&cond=|rritable+Bowel+Syndrome\&rank=1 .

57 Thompson WG, Longstreth GF, Drossman DA, et al. Functional bowel disorders and functional abdominal pain. Gut 1999;45(Suppl 2):ii43-7.

58 Longstreth GF, Thompson WG, Chey WD, et al. Functional bowel disorders. Gastroenterology 2006:130:1480-91.

59 Drossman DA, Thompson WG, Talley NJ. Identification of sub-groups of functional gastrointestinal disorders. Gastroenterology Int/ 1990;3:159-72.

60 Ford AC, Bercik P, Morgan DG, et al. Validation of the Rome III criteria for the diagnosis of irritable bowel syndrome in secondary care. Gastroenterology 2013:145:1262-70.

61 Jones RH, Holtmann G, Rodrigo L, et al. Alosetron relieves pain and improves bowe function compared with mebeverine in female nonconstipated irritable bowel syndrome patients. Aliment Pharmacol Ther 1999;13:1419-27.

62 Lee KJ, Kim NY, Kwon JK, et al. Efficacy of ramosetron in the treatment of male patients with irritable bowel syndrome with diarrhea: a multicenter randomized clinical trial, compared with mebeverine. Neurogastroenterol Motil 2011;23:1098-104

63 Olden KW, Chey WD, Shringarpure R, et al. Alosetron versus traditional pharmacotherapy in clinical practice: effects on resource use, health-related quality of life, safety and symptom improvement in women with severe diarrhea-predominant irritable bowel syndrome. Curr Med Res Opin 2019;35:461-72.

64 Burr NE, Ford AC. Assessing the efficacy of peripherally acting $\mu$-opioid receptor antagonists (PAMORAs) in the treatment of opioid-induced constipation: authors reply. Gut 2019;68:1530-1. 